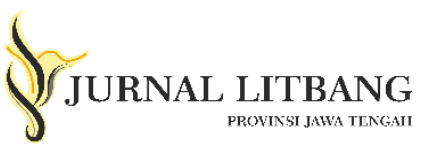

\begin{tabular}{l}
\hline Info Artike \\
\hline Diterima : 20 \\
Direvisi : 8 \\
Disetujui : 22 \\
\\
Kata kunci: \\
Efektivitas \\
Temu teknis \\
Peneliti \\
Penyuluh \\
Adaptasi \\
Teknologi
\end{tabular}

Keywords:

Effectiveness

Technical meetings

Researchers

Extension workers

Adaptation

Technology

Corresponding Author:

Restu Hidayah

Restuhidayah2016@gmail.com

085641041590

BPTP Jawa Tengah

\section{Keragaan Tingkat Pengetahuan, Persepsi dan Respon Pada Peserta Temu Teknis Peneliti- Penyuluh Balitbangtan dan Penyuluh Jawa} Tengah

The Level of Knowledge, Perceptions and Responses of Participants the Technical Meeting Balitbangtan Extension-Researchers and Central Java Extension

\author{
Restu Hidayah, Fitri Lestari, Nurul Laela Fatmawati, \\ Ekaningtyas Kushartanti \\ BPTP Jawa Tengah
}

\begin{abstract}
Abstrak
Kegiatan temu teknis peneliti-penyuluh bertujuan untuk membekali penyuluh dalam melaksanakan Kegiatan Adaptasi Teknologi Spesifik Lokasi tahun 2020 pada 12 kabupaten di Jawa Tengah. Materi dalam temu teknis ini adalah beberapa inovasi teknologi Balitbangtan sebagai alternatif pilihan inovasi teknologi yang akan diterapkan. Evaluasi pelaksanaan temu teknis merupakan indikator keberhasilan suatu penyuluhan dilihat dari peningkatan pengetahuan, persepsi dan respon peserta. Tujuan dari makalah ini adalah untuk mengetahui keragaan tingkat pengetahuan peserta serta mengetahui persepsi dan respon peserta temu teknis. Parameter yang diamati adalah karakteristik responden, keragaan tingkat pengetahuan, persepsi, dan respon peserta Teтu Teknis. Pengumpulan data dilakukan melalui survei dengan menggunakan kuesioner, yang selanjutnya diolah dengan analisis non-parametrik dan deskriptif. Hasil kajian menunjukkan bahwa pengetahuan responden meningkat sebesar 49,01\%. Responden memberikan persepsi dan respon yang positif pada level tinggi terhadap penyelenggaraan temu teknis ini karena sangat bermanfaat dalam menunjang tupoksinya.
\end{abstract}

Abstract
The technical meeting for Researcher-Extension Workers aims
to train the extension workers, who carry out the Specific
Technology Adaptation 2020 in 12 districts in Central Java. In this
technical meeting, several technological innovations of
Balitbangtan were presented as alternative choices of
technological innovations to be applied. Evaluation of technical
meetings is an indicator of the success of an extension seen from
the increase in knowledge, perceptions and responses of
participants. The purpose of this paperis to identify the knowledge
level of the participants, identify the perceptions, and also
responses of participants. The observed parameters are the
characteristics of the respondents, the level of knowledge,
perceptions and responses of the respondents. Data was collected
through survey by questionnaire and analyzed it with non-
parametric analysis and descriptive. The study results that
respondent's knowledge increase 49,01\%. Respondents give
perceptions and responses on high-level of assessment for the
benefit of technical meeting because it is very helpful to
supporttheir main tasks and functions.




\section{PENDAHULUAN}

Kementerian Pertanian Tahun 20202024 mempunyai visi terwujudnya kedaulatan pangan dan kesejahteraan petani serta indonesia sebagai lumbung pangan dunia pada tahun 2045. Tujuan pembangunan pertanian adalah menyediakan pangan untuk 267 juta jiwa, meningkatkan kesejahteraan petani, dan meningkatkan ekspor. Dalam pelaksanaan pembangunan pertanian tersebut dicanangkan tiga kunci sukses, yaitu Maju, Mandiri dan Modern. Selanjutnya, ada empat fokus yang menjadi perhatian Kementerian Pertanian, yaitu (1) Gerakan Nasional Peningkatan Produksi, (2) Menurunkan Biaya Pertanian melalui Peningkatan Efisiensi dan Pengembangan Kawasan Korporasi, (3) Pengembangan mekanisasi dan inovasi teknologi, dan (4) Ekspansi Pertanian (lahan Rawa, lahan Sub Optimal, Penyediaan Air) (Kementerian Pertanian, 2020).

Badan Penelitian dan Pengembangan Pertanian (Balitbangtan) menghasilkan inovasi baru, berupa teknologi, konsep, model, dan metodologi, yang harus segera disampaikan kepada pengguna teknologi, yaitu penentu kebijakan, penyuluh pertanian dan petani. Badan Litbang pertanian maupun BPTP berfungsi untuk mendiseminasikan teknologi dan menjadi fasilitator dalam penggalian kebutuhan pengguna akhir untuk menciptakan teknologi baru (Sirnawati dan Syahyuti, 2018). BPTP Jawa Tengah, sebagai perwakilan Balitbangtan di Jawa Tengah, mendiseminasikan inovasi teknologi pertanian yang dihasilkan Balitbangtan, salah satunya melalui kegiatan Temu Teknis. Temu Teknis adalah kegiatan pertemuan berkala antar Penyuluh Pertanian, atau antara Penyuluh Pertanian, Peneliti dan Aparat Pengaturan dan Pelayanan untuk meningkatkan pelayanan kepada petani dalam mengembangkan usahataninya. Temu teknis ini diharapkan dapat memberikan alternatif materi untuk kegiatan adaptasi teknologi spesifik lokasi.
Kegiatan Adaptasi Teknologi Spesifik Lokasi di Jawa Tengah dilaksanakan pada 20 Balai Penyuluhan Pertanian (BPP) di 12 kabupaten, yaitu Cilacap, Banyumas, Purbalingga, Wonogiri, Karanganyar, Semarang, Temanggung, Grobogan, Blora, Jepara, Wonosobo, dan Pati. Kegiatan ini merupakan sinergi antara BPTP Jawa Tengah dengan Dinas Pertanian dan Perkebunan Provinsi Jawa Tengah, berupa: pengembangan Kelembagaan Ekonomi Petani, (2) demfarm, (3) demplot atau percontohan di lahan BPP atau sekitar BPP dengan budidaya produk unggulan dan kegiatan adaptasi produk unggulan berpotensi di masing-masing daerah. Kegiatan ini diharapkan bisa menjadi wahana pembelajaran untuk penyuluh dan masyarakat sekitar.

Efektivitas penyuluhan adalah suatu keadaan yang menunjukkan tingkat keberhasilan penyuluhan pertanian oleh penyuluh setempat dalam mencapai tujuan yang telah ditetapkan. Tujuan penyuluhan yang ingin dicapai yaitu meningkatkan pengetahuan, ketrampilan dan sikap khususnya petani sehingga mereka akan mampu untuk mandiri, karena tanpa adanya penambahan pengetahuan dan ketrampilan serta perbaikan sikap, mereka akan sulit memperbaiki kehidupan mereka. Persepsi adalah kemampuan panca indera dalam menerjemahkan stimulus atau proses untuk menerjemahkan stimulus yang masuk ke dalam alat indera manusia (Sugihartono, 2007). Persepsi melalui tiga tahapan, yaitu pemaparan, perhatian, dan pemaknaan (Solomon, 2002). Persepsi dipengaruhi oleh umur, pengalaman, dan kondisi usahatani responden (Marsaulina et al., 2014). Respon adalah hasil dari perilaku stimulus, yaitu aktivitas dari orang yang bersangkutan, tanpa memandang apakah stimulus tersebut dapat diidentifikasikan atau tidak dapat diamati. Respon akan terkait dengan stimulus, sehingga jika stimulus terjadi maka suatu respon akan mengikuti (Gibson et al, 1988). 
Tujuan kajian ini adalah untuk mengetahui keragaan tingkat pengetahuan peserta sebelum dan sesudah penyelenggaraan penyuluhan, serta mengetahui persepsi dan respon peserta temu teknis. Hasil kajian ini diharapkan dapat menjadi bahan evaluasi untuk penyelenggaraan temu teknis atau kegiatan serupa di kemudian hari.

\section{METODE PENELITIAN}

Temu Teknis Peneliti-Penyuluh Balitbangtan dan Penyuluh Jawa Tengah dalam rangka sinergi kegiatan Adaptasi Teknologi Spesifik Lokasi dilaksanakan di Gedung Serba Guna, BPTP Balitbangtan Jawa Tengah, Bergas, Kabupaten Semarang, pada tanggal 12 Maret 2020. Kegiatan ini diikuti oleh 50 orang peserta dari penyuluh BPP, penyuluh pertanian pada Dinas Pertanian dan Perkebunan Provinsi Jawa Tengah, dan unsur struktural/staf/penyuluh pada dinas teknis pertanian di kabupaten yang melaksanakan Kegiatan Adaptasi Spesifik Lokasi. Kegiatan Temu Teknis Peneliti-Penyuluh Balitbangtan dan Penyuluh Jawa Tengah dalam rangka sinergi Kegiatan Adaptasi Teknologi Spesifik Lokasi pada Balai Penyuluhan Pertanian (BPP), terdiri dari materi di dalam kelas dan praktik lapang. Secara spesifik, materi yang disampaikan meliputi komponen teknologi peningkatan produktivitas padi sebanyak $7 \%$, inovasi teknologi budidaya cabai, budidaya bawang merah menggunakan benih asal umbi dan biji, teknologi pengelolaan lahan pekarangan dan praktik lapang dengan materi pembibitan bawang merah menggunakan media Soil Block, Vertikultur, Irigasi tetes, serta budidaya sayuran secara hidroponik dan aquaponik.

Materi dalam kegiatan temu teknis dipilih berdasarkan kebutuhan di lapangan, yang didasarkan pada penurunan luas lahan pertanian (Kementerian Perencanaan Pembangunan Nasional, 2013), sulitnya akses permodalan, dan rendahnya penerapan teknologi pertanian (Sembiring, 2017).

Pengkajian efektivitas Temu Teknis Peneliti-Penyuluh Balitbangtan dan Penyuluh Jawa Tengah dalam rangka sinergi kegiatan
Adaptasi Teknologi Spesifik Lokasi dilaksanakan dengan menggunakan kuesioner, yang diisi oleh peserta kegiatan Temu Teknis. Responden berjumlah 36 orang, yang merupakan peserta Temu Teknis. Data yang dikumpulkan meliputi data karakteristik responden, keragaan tingkat pengetahuan, persepsi dan respon peserta Temu Teknis, serta penilaian peserta terhadap penyelenggaraan kegiatan Temu Teknis.

Keragaan tingkat pengetahuan responden diolah dan dianalisis dari data hasil pre test dan post test. Data tersebut ditabulasi, dibandingkan dengan hasil pre test dan hasil post test, selanjutnya dianalisis menggunakan analisis statistik nonparametrik dengan uji Wilcoxon Match Pairs Test. Pengujian ini dilakukan dengan membandingkan nilai hasil pre test dan post test untuk menguji signifikansi dua subyek penelitian berpasangan (Ernawati, dkk, 2012). Analisis uji Wilcoxon Match Pairs Test merupakan analisis pengujian keefektifan (Narbuko, 2004). Data tingkat persepsi dan repon yang terkumpul dianalisis dengan metode deskriptif menggunakan konsep ukuran frekuensi, persentase, kisaran dan rata-rata. Persepsi dan respon responden akan diklasifikasikan menjadi tiga kategori, yakni tinggi, sedang dan rendah. Untuk mencari interval kelas digunakan formula sebagai berikut (Azwar, 2002).

\section{$\mathbf{I}=\mathbf{J} / \mathbf{K}$}

Keterangan :

I : interval kelas

$\mathrm{J}$ : Jarak (nilai terbesar dikurangi nilai terkecil)

$\mathrm{K}$ : banyaknya kelas yang digunakan (ada 3 kelas).

\section{HASIL DAN PEMBAHASAN}

Kegiatan temu teknis diikuti oleh 48 orang, yang terdiri dari unsur penyuluh pertanian dari BPP pelaksana kegiatan adaptasi teknologi spesifik lokasi (sebanyak 20 BPP), unsur struktural/staf pada dinas teknis pertanian kabupaten lokasi adaptasi spesifik lokasi di 12 kabupaten, penyuluh 
pertanian pada Dinas Pertanian dan Perkebunan Provinsi Jawa Tengah, dan penyuluh dan peneliti BPTP Jawa Tengah.

Materi yang disampaikan secara garis besar difokuskan pada empat topik utama, antara lain: (1) komponen teknologi peningkatan produktivitas padi, (2) inovasi teknologi budidaya cabai, (3) inovasi teknologi budidaya bawang merah dan (4) inovasi teknologi pengelolaan lahan pekarangan. Metode pembelajaran yang dilaksanakan pada kegiatan temu teknis melalui dua cara, yaitu (1) ceramah yang disampaikan di dalam ruang pertemuan, dengan menggunakan LCD, dan dilanjutkan diskusi tanya jawab, serta (2) praktik yang dilaksanakan di luar ruangan (di pekarangan BPTP Jawa Tengah), dan dilanjutkan diskusi tanya jawab.

Responden dalam evaluasi penyelenggaraan penyuluhan Temu Teknis Peneliti-Penyuluh Balitbangtan dan Penyuluh Jawa Tengah dalam rangka sinergi kegiatan Adaptasi Teknologi Spesifik Lokasi adalah peserta yang berjumlah 36 orang. Karakteristik responden kegiatan Temu Teknis dilihat dari parameter umur, tingkat pendidikan, sebagaimana disajikan pada Tabel 1. Dari informasi pada Tabel 1, sebagian besar responden adalah penyuluh senior yang berumur lebih dari 50 tahun (sebesar 47,22\%). Berdasarkan tingkat pendidikan, peserta termasuk dalam kategori berpendidikan tinggi, bahkan ada yang menempuh pendidikan sampai S2.

Tabel 1. Karakteristik responden

\begin{tabular}{clc}
\hline No & \multicolumn{1}{c}{$\begin{array}{c}\text { Karakteristik } \\
\text { Responden }\end{array}$} & $\begin{array}{c}\text { Persentase } \\
(\%)\end{array}$ \\
\hline Umur & \\
\hline $\mathbf{1}$ & $<40$ tahun & 36,11 \\
\hline $\mathbf{2}$ & $40-49$ tahun & 16,67 \\
\hline $\mathbf{3}$ & $\geq 50$ tahun & 47,22 \\
\hline \multicolumn{2}{l}{ Pendidikan } \\
\hline $\mathbf{1}$ & SLTA & 5,56 \\
\hline $\mathbf{2}$ & D3 & 2,78 \\
\hline $\mathbf{3}$ & D4/S1 & 83,33 \\
\hline $\mathbf{4}$ & S2 & 8,33 \\
\hline
\end{tabular}

Sumber: Data Primer, 2020
Dengan tingkat pendidikan yang tinggi, diharapkan responden dapat menerima materi Temu Teknis dengan baik dan mampu meneruskannya kepada petani, sebagai pelaku utama dan pelaku usaha pada kegiatan usahatani

\section{Tingkat Pengetahuan Penyuluh/Petugas Pertanian}

Keefektifan kegiatan Temu Teknis Peneliti-Penyuluh Balitbangtan dan Penyuluh Jawa Tengah salah satunya dinilai dari peningkatan pengetahuan penyuluh pertanian peserta Temu Teknis tersebut. Untuk mengukur peningkatan pengetahuan peserta Temu Teknis, dilaksanakan survei pengisian kuesioner pre-test dan post-test. Hasil evaluasi peningkatan pengetahuan peserta Temu Teknis menunjukkan bahwa rata-rata terjadi peningkatan pengetahuan setelah mengikuti kegiatan Temu Teknis sebesar 49,01\% (Tabel 2). Keragaan peningkatan pengetahuan peserta Temu Teknis, yang

Bisa diuraikan secara simultan dalam 1 bagian utuh atau dibagi menjadi subbagian hasil dan pembahasan. Jika dibagi dalam hasil dan pembahasan diuraikan sebagai berikut: dibandingkan dari sebelum dan sesudah mendapatkan materi Temu Teknis disajikan pada gambar 1.

Pada Gambar 1, dapat dilihat bahwa persentase jawaban yang benar dari responden pada saat dilaksanakan post-test (garis berwarna merah) di atas hasil pre-test (garis berwarna biru). Hampir seluruh responden (35 orang) memiliki nilai post-test lebih tinggi dari nilai pre-test, dan hanya ada 1 responden yang memiliki nilai pre-test dan post-test sama. Hasil pre test dan post test tersebut (Tabel 3) selanjutnya dianalisis dengan analisis statistik non parametrik uji Wilcoxon Match Pairs Test. 


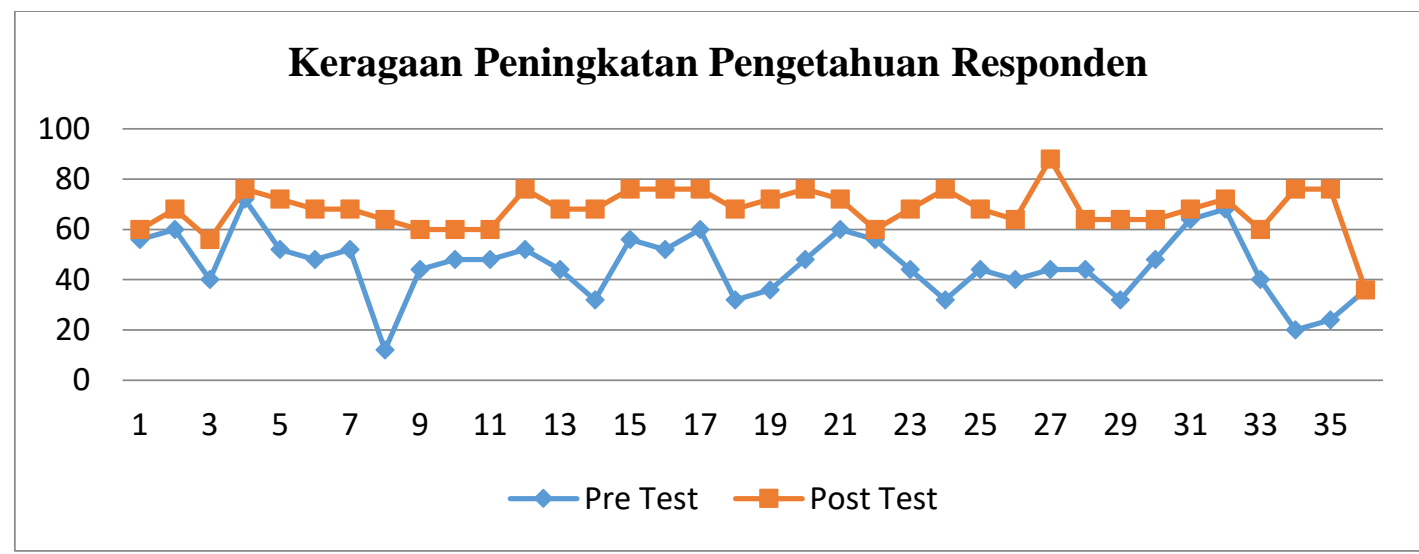

Gambar 1. Keragaan Peningkatan Pengetahuan Responden Sumber: Olah data, 2020

Tabel 2. Hasil Pre-test dan Post-test Responden

\begin{tabular}{|c|c|c|c|c|c|}
\hline Responden & Pre-test & Post-test & Responden & Pre-test & Post-test \\
\hline 1 & 56 & 60 & 19 & 36 & 72 \\
\hline 2 & 60 & 68 & 20 & 48 & 76 \\
\hline 3 & 40 & 56 & 21 & 60 & 72 \\
\hline 4 & 72 & 76 & 22 & 56 & 60 \\
\hline 5 & 52 & 72 & 23 & 44 & 68 \\
\hline 6 & 48 & 68 & 24 & 32 & 76 \\
\hline 7 & 52 & 68 & 25 & 44 & 68 \\
\hline 8 & 12 & 64 & 26 & 40 & 64 \\
\hline 9 & 44 & 60 & 27 & 44 & 88 \\
\hline 10 & 48 & 60 & 28 & 44 & 64 \\
\hline 11 & 48 & 60 & 29 & 32 & 64 \\
\hline 12 & 52 & 76 & 30 & 48 & 64 \\
\hline 13 & 44 & 68 & 31 & 64 & 68 \\
\hline 14 & 32 & 68 & 32 & 68 & 72 \\
\hline 15 & 56 & 76 & 33 & 40 & 60 \\
\hline 16 & 52 & 76 & 34 & 20 & 76 \\
\hline 17 & 60 & 76 & 35 & 24 & 76 \\
\hline 18 & 32 & 68 & 36 & 36 & 36 \\
\hline \multicolumn{2}{|c|}{ Total pre-test } & 1640 & \multicolumn{2}{|c|}{ Total post-test } & 2444 \\
\hline \multicolumn{2}{|c|}{ Rata-rata } & 45,56 & \multicolumn{2}{|c|}{ Rata-rata } & 67,89 \\
\hline
\end{tabular}

Sumber: Data Primer, 2020

Hasil dari analisis statistik non pada taraf kesalahan $5 \%$, nilai $\mathrm{Z}$ tabel $=1,64$. parametrik uji Wilcoxon Match Pairs Test Dengan demikian, nilai Z hitung lebih besar yang dilakukan dapat dilihat pada Tabel 3. dari $\mathrm{Z}$ tabel, maka dapat disimpulkan bahwa Hasil analisis uji Wilcoxon, dengan $\mathrm{n}=36$, kegiatan Temu Teknis yang dilakukan dan taraf kesalahan 5\%, menunjukkan nilai menggunakan metode ceramah, tanya jawab Asymp. Sig. 0,000 (Asymp. Sig. $\leq 0,05$ ), serta dan praktik berpengaruh signifikan dalam nilai $\mathrm{Z}$ hitung pada uji Wilcoxon adalah - meningkatkan pengetahuan peserta Temu 5,169 merupakan nilai mutlak. Selanjutnya, Teknis. 
Peningkatan pengetahuan responden tersebut, tidak terlepas dari peran narasumber yang kompeten dalam memberikan materi, di samping adanya praktik dalam penyampaian materi Temu Teknis tersebut. Metode ceramah memberikan pengaruh yang signifikan dalam peningkatan pengetahuan responden (Hidayah et al., 2020).

Pendidikan menjadi salah satu faktor penentu keberhasilan dalam suatu kegiatan penyuluhan. Responden dalam kegiatan temu teknis ini $83,33 \%$ memiliki pendidikan DIV/S1 dan sebanyak $8,33 \%$ berpendidikan S2. Tingkat pendidikan ini termasuk dalam kategori pendidikan tinggi, dan berdampak positif terhadap efektivitas penyuluhan. Responden dengan tingkat pendidikan tinggi akan relatif lebih cepat dalam menerima dan melaksanakan adopsi inovasi (Daliana dan Nasriati, 2017).

Tabel 3. Analisis Statistik Uji Wilcoxon Match Pairspre-test dan post-test Tentang Peningkatan Pengetahuan Responden ( $\mathrm{n}=36)$

\begin{tabular}{lcccc}
\hline & N & Mean Rank & Sum of Ranks \\
\hline Post test - Pre test & Negative Ranks & $0^{\mathrm{a}}$ & 0,00 & 0,00 \\
& Positive Ranks & $35^{\mathrm{b}}$ & 18,00 & 630,00 \\
& $1^{\mathrm{c}}$ & & \\
& Total & 36 & & $-5,169^{\mathrm{b}}$ \\
Z & & 0,000 \\
Asymp. Sig. (2-tailed) & \\
a. Post test $<$ Pre test & & \\
b. Post test $>$ Pre test & & \\
c. Post test $=$ Pre test & & \\
\hline Sumber: Hasil Olah Data, 2020
\end{tabular}

Persepsi Penyuluh/Petugas Pertanian Teknis (Tabel 4). Seluruh responden Terhadap Materi Temu Teknis menyatakan bahwa: (1) materi yang Hasil evaluasi persepsi penyuluh/ disampaikan dalam Temu Teknis merupakan petugas pertanian terhadap materi Temu teknologi baru, (2) materi Temu Teknis sesuai Teknis menunjukkan bahwa semua penyuluh/ kebutuhan, (3) materi yang disampaikan petugas pertanian $(100 \%)$ mempunyai tingkat persepsi tinggi/positif terhadap materi Temu menambah pengetahuan/wawasan, (4) materi yang disampaikan bermanfaat mendukung tugas sebagai penyuluh/petugas pertanian, dan (5) materi yang disampaikan mudah untuk dipahami.

Tabel 4. Persepsi Responden Terhadap Materi Temu Teknis

\begin{tabular}{ccc}
\hline Kategori Persepsi (Skor) & Jumlah (Orang) & Persentase (\%) \\
\hline Rendah $(20-33,3)$ & 0 & 0,00 \\
Sedang $(33,4-46,7)$ & 0 & 0,00 \\
Tinggi $(46,8-60)$ & 36 & 100,00 \\
\hline \multicolumn{1}{c}{ Jumlah } & 36 & 100,00 \\
\hline
\end{tabular}

Sumber: Hasil Olah Data, 2020 
Tabel 5. Komponen Persepsi Responden terhadap kemanfaatan materi Temu Teknis

\begin{tabular}{llccc}
\hline \multirow{2}{*}{ No } & \multicolumn{2}{c}{ Komponen Persepsi } & \multicolumn{3}{c}{ Persepsi Responden (\%) } \\
\cline { 3 - 5 } & \multicolumn{1}{c}{ Tinggi } & Sedang & Rendah \\
\hline 1 & Materi yang disampaikan merupakan teknologi baru & 94,44 & 5,56 & 0,00 \\
2 & Materi yang disampaikan sesuai kebutuhan & 97,22 & 2,78 & 0,00 \\
3 & Materi yang disampaikan menambah & & & \\
& pengetahuan/wawasan & 97,22 & 2,78 & 0,00 \\
4 & Materi yang disampaikan bermanfaat & 100,00 & 0,00 & 0,00 \\
5 & Materi yang disampaikan mudah dipahami & 94,44 & 5,56 & 0,00 \\
\hline \multicolumn{1}{r}{ Rata-Rata } & $\mathbf{9 6 , 6 6}$ & $\mathbf{3 , 3 4}$ & $\mathbf{0 , 0 0}$ \\
\hline
\end{tabular}

Tingkat persepsi responden dipengaruhi oleh budaya, sikap terhadap perubahan, keyakinan kemampuan diri, tingkat keberanian berisiko, tingkat intelegensia, rasionalitas, kerjasama, peran dalam kelompok tani dan intensitas penyuluhan (Suharyanto et al., 2017). Responden memberikan persepsi yang tinggi (tabel 4) karena materi temu teknis sesuai dengan kebutuhan responden untuk mendukung kinerja mereka (tabel 5). Kesesuaian materi temu teknis dengan kebutuhan responden membuat tingkat persepsi responden tinggi (Hidayah et al, 2020). Materi yang sesuai dengan kebutuhan bisa menjadi motivasi tersendiri untuk responden. Keragaman persepsi responden dipengaruhi oleh beberapa faktor, seperti karakteristik pribadi (umur, pendidikan, masa kerja), lingkungan dan motivasi (Narso et al,. 2012). Umur responden juga berpengaruh terhadap keragaan tingkat persepsi. Dalam kegiatan ini, sebagian besar responden berumur di atas 50 tahun (tabel 1).

Varietas Unggul Baru Padi berperan penting dalam meningkatkan produktivitas padi (Nurhati et al., 2008). Jika suatu varietas ditanam secara terus menerus, maka produktivitasnya akan menurun dan rentan terhadap serangan hama dan penyakit (Putra dan Haryati, 2018). Pada lahan tadah hujan, Inpago 9 yang ditanam dengan sistem jarwo $2: 1$, memberikan produktivitas terbaik (Kushartanti et al., 2019). Untuk lahan sawah irigasi, Inpari 43, masih menjadi primadona petani karena keragaan tanaman menarik, hasil padi tinggi, jumlah anakan produktif banyak, tidak mudah rebah, dan lebih tahan terhadap penyakit (Hidayah et al., 2019).

Bawang merah merupakan salah satu komoditas hortikultura dengan harga yang sangat fluktuatif. Berbagai penelitian telah dilakukan untuk meningkatkan produktivitas bawang merah dengan berbagai kondisi lingkungan. Pada lahan sub optimal, budidaya bawang merah asal biji dengan benih umur 6 minggu dan kerapatan 150 tanaman per $\mathrm{m}^{2}$ menghasilkan pertumbuhan tanaman dan hasil umbi yang maksimal (Sopha et al., 2017). Penggunaan umbi ukuran sedang sebagai benih menghasilkan produktivitas terbaik (Azmi et al., 2011).

Permasalahan yang dihadapi petani cabai adalah tingginya serangan hama dan penyakit. Hama yang sering menyerang adalah thrips, lalat buah, kutu kebul, kutu daun persik dan kutu daun. Untuk mengendalikan hama thrips dapat digunakan tanaman perangkap, seperti kenikir, menggunakan mulsa perak, sanitasi lingkungan, penggunaan perangkap kuning, dan pemanfaatan musuh alami yang potensial. Penyakit yang sering menyerang tanaman cabai adalah layu fusarium, busuk buah, layu bakteri, bercak daun, dan virus kuning. Penyakit virus kuning dapat dikendalikan dengan mengendalikan serangga vectornya, yaitu kutu kebul, penanaman varietas tahan, seperti hotchili, sanitasi lingkungan, pemupukan tambahan untuk meningkatkan daya tahan tanaman, perendaman benih, penggunaan mulsa plastik, dan penanaman tanaman pembatas (Meilin, 2014). 


\section{Persepsi Penyuluh/Petugas Pertanian Terhadap Penyelenggaraan Kegiatan Temu Teknis Peneliti, Penyuluh Balitbangtan dan Penyuluh Jawa Tengah}

Hasil evaluasi persepsi dan respon penyuluh/petugas pertanian terhadap penyelenggaraan kegiatan Temu Teknis disajikan pada Tabel 6. Indikator yang digunakan untuk menilai keragaan persepsi penyuluh/petugas pertanian terhadap penyelenggaraan Temu Teknis adalah (1) ketepatan metode yang digunakan dalam penyampaian materi Temu Teknis, materi dalam ruang pertemuan dengan tanya jawab dan praktik, (2) Metode penyampaian materi dengan praktik lapang pada Temu Teknis diharapkan memperjelas materi yang disampaikan, (3) Kesesuaian/ketepatan proporsi waktu penyampaian materi dalam ruangan dan praktik, serta(4) Kesesuaian penggunaan sarana prasarana yang digunakan untuk praktik. Hasil evaluasi menunjukkan bahwa semua penyuluh/petugas pertanian (100\%) mempunyai persepsi dan respon tinggi/positif terhadap penyelenggaraan kegiatan Temu Teknis Peneliti, Penyuluh BPTP, dan Penyuluh Jawa Tengah.

\section{Respon Penyuluh/Petugas Pertanian Terhadap Penyelenggaraan Kegiatan Temu Teknis Peneliti, Penyuluh Balitbangtan dan Penyuluh Jawa Tengah}

Respon responden penyuluh/ petugas pertanian terhadap penyelenggaraan kegiatan Temu Teknis Peneliti, Penyuluh Balitbangtan, dan Penyuluh Jawa Tengah dinilai dengan indikator (1) materi Temu Teknis akan digunakan sebagai materi penyuluhan, (2) materi Temu Teknis akan digunakan untuk kegiatan Uji Adaptasi Spesifik Lokasi, (3) materi Temu Teknis akan dipraktikkan di lapangan, (4) materi Temu Teknis akan dijadikan referensi pelaksanaan penyuluhan, dan (5) materi Temu Teknis akan disampaikan kepada penyuluh di wilayah kerja masingmasing. Hasil evaluasi respon tersebut disajikan pada Tabel 6 .
Tabel 6. Respon Responden

\begin{tabular}{lcc}
\hline $\begin{array}{l}\text { Kategori } \\
\text { Respon (Skor) }\end{array}$ & $\begin{array}{c}\text { Jumlah } \\
\text { (Orang) }\end{array}$ & $\begin{array}{c}\text { Persent } \\
\text { ase (\%) }\end{array}$ \\
\hline $\begin{array}{l}\text { Rendah }(5,00- \\
8,33)\end{array}$ & 0 & 0,00 \\
$\begin{array}{l}\text { Sedang }(8,34- \\
\begin{array}{l}11,67) \\
\text { Tinggi }(11,68-\end{array}\end{array}$ & 2 & 5,56 \\
\begin{tabular}{l} 
15,00) \\
\multicolumn{1}{c}{ Jumlah }
\end{tabular} & 34 & 94,44 \\
\hline
\end{tabular}

Sumber: Hasil Olah Data, 2020

Dari Tabel 6, dapat dilihat bahwa sebagian besar responden masih memberikan respon yang tinggi terhadap penyelenggaraan temu teknis ini. Hal ini dipengaruhi oleh tingginya persepsi responden (Tabel 6), seperti halnya yang disampaikan oleh Wijaya et al. (2015), di mana respon responden berkorelasi positif dengan persepsi. Pendidikan dan pengalaman responden merupakan faktor yang berpengaruh terhadap respon (Rozalina dan Tusiah, 2015). Tingkat pendidikan yang tinggi dan masa kerja yang cukup lama akan mempengaruhi responden dalam memberikan respon yang tinggi. Ada 5,56\% responden yang memberikan respon sedang, yang mana hal ini mengindikasikan adanya keraguraguan pada respon responden. Keraguan ini dimungkinkan karena adanya ketidaksesuaian dalam menerapkan teknologi pada karakteristik wilayah kerja responden.

\section{SIMPULAN}

Temu teknis Peneliti-Penyuluh Balitbangtan dan Penyuluh Jawa Tengah dapat meningkatkan pengetahuan peserta sebesar 49,01\%. Responden memberikan persepsi yang tinggi pada kegiatan temu teknis ini. Sebagian besar responden memberikan respon yang tinggi terhadap penyelenggaraan temu teknis ini.

\section{DAFTAR PUSTAKA}

Azmi, C., M. Hidayat dan G. Wiguna. 2011. Pengaruh Varietas dan Ukuran Umbi Terhadap Produktivitas Bawang Merah. J. Hort 21(3): 206-213 
Jurnal Litbang Provinsi Jawa Tengah, Vol. 19, No. 1, Juni 2021, hal. 71 80

Azwar, S. 2002. Sikap Manusia, Teori dan Pengukurannya. Edisi ke-2. Pustaka Pelajar, Yogyakarta.

Daliana S.D dan Nasriati. 2017. Pengetahuan Petani Terhadap Teknologi Pengelolaan Tanaman Terpadu (PTT) Padi Sawah di Kabupaten Seluma. Prosiding Seminar Agroinovasi Spesifik Lokasi Untuk Ketahanan Pangan Pada Era Masyarakat Ekonomi ASEAN.

Ernawati, S., Lutojo, Irianto, H., Rahayu1, T.H. Sari, I.A. 2012. Efektivitas Model Pelatihan Keterampilan berbasis Usaha Pertanian-Peternakan Terpadu Pasca Bencana Erupsi Gunung Merapi di Kecamatan Selo, Kabupaten Boyolali. Sains Peternakan Vol. 10 (2), 85-92.

Gibson, James et al. 1998. Organisasi dan Manajemen: Perilaku, Struktur, Proses, Edisi keempat. (Terjemahan). Erlangga, Jakarta.

Hidayah, R., S. Catur, E. Kushartanti, Warsana. 2019. Persepsi dan Preferensi Petani Terhadap Padi Varietas Unggul Baru Balitbangtan (Studi Kasus di Kelompok Tani Sri Mulyo Kabupaten Tegal). Prosiding Konser Karya Ilmiah Nasional 2019 “Kesiapan Sumber Daya Manusia Pertanian menghadapi Revolusi Industri 4.0"

Hidayah, R., G.N Oktaningrum, D. Dini, S.D Anomsari, I. Ambarsari. 2020. Efektivitas Sosialisasi Aplikasi teknologi Ozon Pada Penyimpanan Benih Kedelai di Kabupaten Grobogan. Prosiding Seminar Nasional Kesiapan Sumber Daya Pertanian dan Inovasi Spesifik Lokasi Memasuki Era Industri 4.0

Kementerian Pertanian. 2020. Upaya Mewujudkan Pertanian Maju, Mandiri dan Modern. https://paktanidigital.com/artikel. Mei 2021)

Kushartanti, E., D. Sahara, R. Hidayah, T. Suhendrata. 2019. Keragaan Produktivitas dan Kelayakan Usahatani Padi Gogo Varietas Inpago 8 dan Inpago
9 di Kabupaten Boyolali. Prosiding Seminar Nasional Kesiapan Sumber Daya Pertanian dan Inovasi Spesifik Lokasi Memasuki Era Industri 4.0

Marsaulina, M, Herlina, Y. Yumiati. 2014. Persepsi Petani Padi terhadap Kegiatan Penyuluhan Pertanian di Desa Sukarami Kelurahan Taba Penanjung Kabupaten Bengkulu Tengah. Agritepa Vol 1

Meilin, A. 2014. Hama dan Penyakit Pada Tanaman Cabai Serta Pengendaliannya. Balai Pengkajian Teknologi Pertanian Jambi, Jambi.

Narbuko, C dan Abu Achmadi. 2004. Metodologi Penelitian. Bumi Aksara, Jakarta

Narso, A. Saleh, P.S Asngari, P. Muljono. 2012. Persepsi Penyuluh Pertanian Lapang tentang Perannya dalam Penyuluhan Pertanian Padi di Provinsi Banten. Jurnal Penyuluhan Vol 8(1)

Nurhati, I., S. Ramdhaniati, N. Zuraida. 2008. Peranan dan Dominasi Unggul Baru dalam Peningkatan Produksi Padi di Jawa Barat. Buletin Plasma Nutfah Vol.14(1)

Putra, S dan Y. Haryati. 2018. Kajian Produktivitas dan Respon Petani Terhadap Padi Varietas Unggul Baru di Kabupaten Sukabumi, Jawa Barat. Jurnal Pengkajian dan Pengembangan Teknologi Pertanian, Vol 21(1)

Rozalina dan Tusiah. 2015. Faktor-Faktor yang Mempengaruhi Respon Petani Terhadap Penggunaan Mesin Perontok (Power Thresher) Padi (Oryza sativa, L) di Kecamatan Peunaron Kabupaten Aceh Timur. Agrisamudra, Jurnal Penelitian Vol. 2 No. 1

Sembiring, H. 2017. Sasaran Produksi Tanaman Pangan: Strategi dan Operasional. Prosiding Seminar Nasional 2016. Sukamandi: Balai Besar Penelitian Tanaman Padi, Hal. vii-xvi.

Sirnawati, E dan Syahyuti. 2018. Evolusi Evolusi Pembangunan Pertanian di Badan Litbang Pertanian: Dari Transfer Teknologi ke Sistem Inovasi. Forum Penelitian Agro Ekonomi Vol. 36 (1)

Restu Hidayah, Keragaan Tingkat Pengetahuan, Persepsi dan Respon Pada Peserta Temu Teknis 
Solomon, Michael R. 2002. Consumer Behavior Buying, Having and Being. New Jersey, Prentice Hall

Sopha, G. A, M. Syakir, W. Setiawati, Suwandi, N. Sumarni. 2017. Teknik Penanaman Benih Bawang Merah Asal True Shallot Seed di Lahan Suboptimal. J. Hort Vol. 27 (1): 35-44

Sugihartono. 2007. Psikologi Pendidikan. UNY Press, Yogyakarta

Suharyanto, J. Rinaldi, N.N Arya, K. Mahaputra. 2017. Faktor-Faktor Yang Mempengaruhi Persepsi Petani Terhadap Kebijakan Perlindungan Lahan Pertanian pangan Berkelanjutan di Provinsi Bali. Jurnal Pengkajian dan Pengembangan Teknologi Pertanian Vol 20(2):111-124 